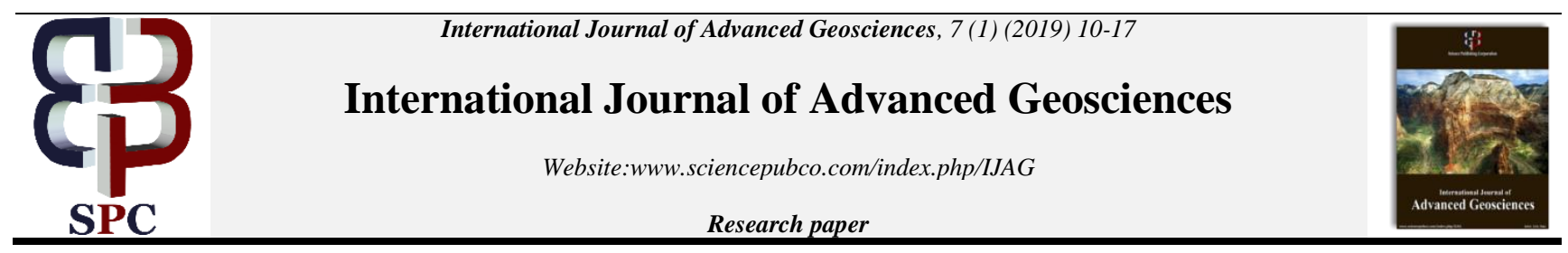

\title{
Sedimentary environments and lithofacies distribution of zeit formation, red sea- Sudan
}

\author{
Sadam. H.M.A.Eltayib ${ }^{1}$, El Sheikh. M. Abdelrahman ${ }^{2}$, Ali. S. M. Ibrahim ${ }^{3}$, Omar A. O. Al-Imam ${ }^{1}$ \\ ${ }^{I}$ International University of Africa, Faculty of Minerals and Petroleum, Khartoum, Sudan \\ ${ }^{2}$ Al Neelain University, Faculty of Petroleum and Minerals, Khartoum, Sudan \\ ${ }^{3}$ Petroleum Labs, Researches and Studies - Khartoum, Sudan \\ *Corresponding author_E-mail:sadam_h3@yahoo.com
}

\begin{abstract}
The Sudanese red sea coastal plain is geologically characterized by Cenozoic siliciclastic and shallow marine rift related sedimentary sequences. Pliocene-Pleistocene is represented by the thick older gravel unit and the emergent linear reef terraces. In this study, wire line logs besides the investigations of cutting samples were used to investigate the un cored facies successions, to detect changes in grain size distribution, lithology and sedimentary facies and hence to interpret depositional environment. Confirmation of the log behavior using the cores and the cutting samples was undertaken. Furthermore, core to gamma-ray and spontaneous potential log correlations were set up. The lithofacies association and the depositional patterns of Zeit Formation were controlled by allocyclic and autocyclic processes, which include tectonic, palaeo climatic as well as depositional mechanisms. The lithofacies Distribution of Lower Zeit Member shows the southwestern part of the area is dominated by terrestrial to marginal marine partly supra tidal domain where some channel feeders can support the sand distribution from south to north. The central part of the area is dominated by shallow marginal marine to partly supratidal domains. The Middle Zeit Member was dominated by marginal marine to supratidal domain. The Upper Zeit Member repeated pattern of facies distribution being similar to that of Middle Zeit, however the sandy facies influxes increased towards the S. Suakin, Dignaarea, towards Bashayer area and Durwara area from south to north.
\end{abstract}

Keywords: Lithofacies; Allocyclic and Autocyclic; Zeit Formation; Correlations.

\section{Introduction}

The study area lies in NE Sudan and is situated in the Red Sea State. It is bounded by longitudes 37o $30^{\prime}$ E \& 38o $15^{\prime}$ E and latitudes 19 o $00^{\prime} \mathrm{N} \& 22 \mathrm{o} 00^{\prime} \mathrm{N}$.(Fig 1). The main physiographic features in the study area which can be considered are the Red Sea Hills in the west and coastal plain in the east. Generally, high elevation in the west and gradually decreases towards the east .Red Sea Hills are classified as a rugged area with high variation in elevation while coastal plain is smooth and level, without raised or hollow areas [3]. The study area is completely depending on drainage system to provide safe water through Khors and Wadies. The annual average rainfall is between 100 and $190 \mathrm{~mm}$. As the drainage system is structurally controlled, the most of khors and wadis are equbied an areas of faults, fractures and joints [5], [6]. Regarding to the general topography, the surface water is divided by water shad line to the east. According to the little amount of an annual rainfall and with in short season, besides the highly salty soil in coastal area and no perennial streams are known to exist, poor vegetation cover has to be considered. However, bushes and small trees are scattered grown in the wades [1] Fig. (1). 


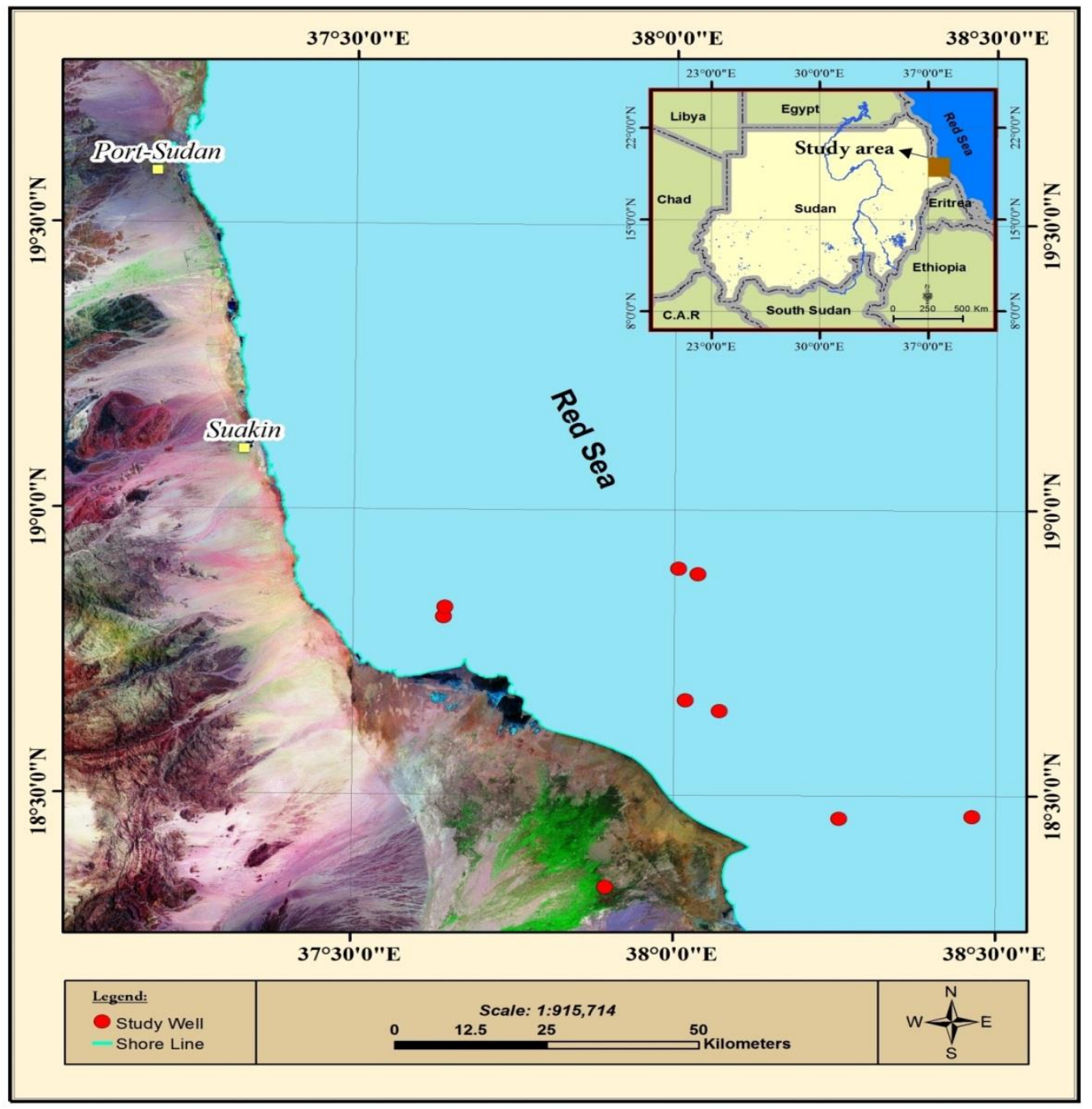

Fig.1 :Location Map of the Study Area.

\section{Strtigraphy}

The stratigraphic sequences are briefly described as follows from top to bottom [5]:

Shagara Formation: It is represented by mixed lithotypes consisting of marine sand/sandstone section intercalated with claystone and partially with thin streaks of dolomite, anhydrite and limestone. It is characterized by loose, colour less, poorly sorted, with traces of mica, slightly glauconitic, traces of carbonaceous matter, feldspars, partly dominated by carbonates of reefal facies. The topmost part is represented by raised beaches and reef terraces in the outcrops being mixed with alluvial fan delta sediments. The thickness ranges between 217-1240m.

Wardan Formation: It is characterized by sandstones and shales with siltstone, thin carbonate interbeded, and evaporite streaks. It is dated as Late Pliocene based on the nannofossil NN18 zone in South Suakin-1well. The formation thickens significantly to the east of the surface water area of delta Tokar. The total thickness of this formation ranging between $410-1140 \mathrm{~m}$.

Zeit Formation: The top anhydrite bed of the Zeit Formation is mainly represented by rapid intercalations between clastics (shale and sandstone) and evaporites (Halite and Anhydrite), that were deposited under lagoonal, deltaic environments with intermittent continental influence. The average thickness of Zeit Formation is about $1800-1900 \mathrm{~m}$. Based on seismic data, the top of the Zeit (UZ) Formation demonstrates a regional unconformity surface, and however the lithology of Tokar-1(St2) and Talla-1(St) wells. The Zeit Formation could be subdivided into three main members mostly separated by unconformity surfaces:

The Upper Zeit member (UZM) is characterized by dark grey shale with anhydrite, salt and sand intercalations, where the lower part of this member have multi variety colour (due to oxidization) of course grained sandstone bed that might represent an unconformity surface. The Upper Zeit could be subdivided into three cycles, from bottom to top namely UZM-A, UZM-B\&UZM- C. The Bashayer-1A well gas bearing reservoir is recorded in the upper part of cycle UZM-B.

The Middle Zeit member (MZM) is characterized by light to dark grey shale, siltstone and thin evaporate streaks and dominance thick red shale beds near the lower part with. It is subdivided into three cycles: namely MZM-A, MZM-B \& MZM-C from base to top. The Suakin-1 hydrocarbon bearing reservoir was encountered in Cycle MZM-A at the lower part of this sub division of this unit.

The Lower Zeit member (LZM) is ended by a relatively thick evaporite unit about $80 \mathrm{~m}$ consist of two beds at depth $2683 \mathrm{~m}$ in Talla-1(St), and extended with thinning to Tokar-1(St2)(20m) rich the depth $2558.5 \mathrm{~m}$. The Cyclicity interpretation could subdivide into four cycles, from bottom to top namely LZM-A, LZM-B, LZM-C and LZM-D.

Dungunab Formation: It is composed of a very thick sequence of evaporites (Halite and anhydrite) with thin beds of shales with a thickness in ranges of 300-900m. The Dungunab Formation is represented by massive salt Formation ranging in thickness from $300 \mathrm{~m}$ in Digna-1 to about $870 \mathrm{~m}$ in Durwara-2 well. 
Belayim Formation: It is encountered in two wells in the area, Durwara-2 and Digna-1 with different facies. In the Durwara- 2 well, the Belayim Formation is represented by sandstone and shale at the top and two main anhydrite beds at the bottom separated by shale interbeds (thickness of $527 \mathrm{~m}$ ). The lithology changes in form of intercalation carbonate facies, thin anhydrite and shale beds. In Digna-1 well the thickness is about thickness of $429 \mathrm{~m}$.

Kareem Formation: It is mainly defined in Durwara-2 well represented by sandstone and shale with a thickness of about $542 \mathrm{~m}$. This formation unconformably overlies metamorphic Basement rocks.

Basement: The igneous rocks in Digna-1 well are mainly undeformed but metamorphosed and intermediate to basic igneous rocks (lower amphibolites facies). The Basement has been appearing in Durwara-2 well.

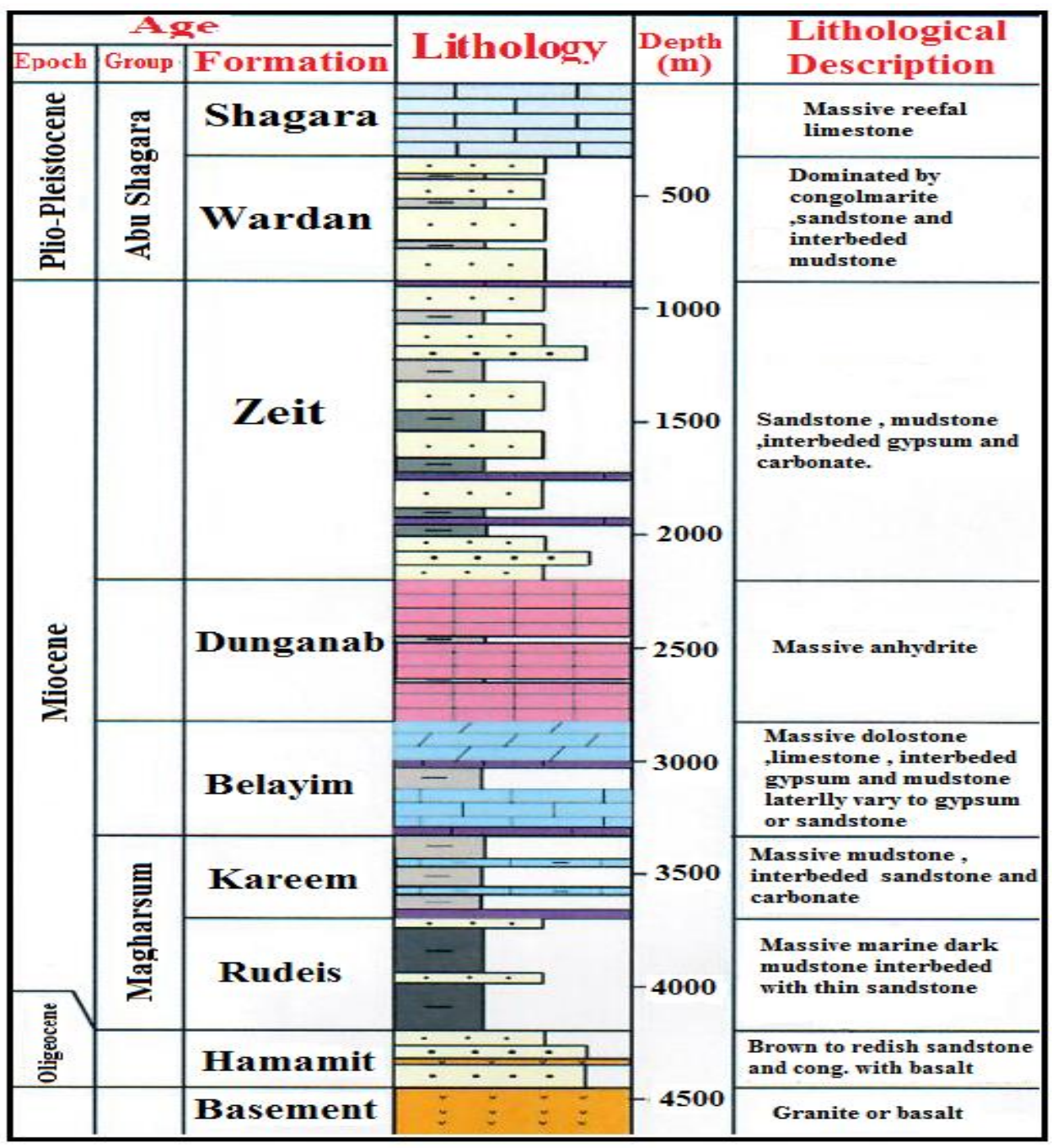

Fig. 2: Lithostratigraphic Column of the Study Area Modified After [5].

\section{Data types}

The data types used in the present study include:

- Wire line logs (gamma-ray and spontaneous potential log).

- Cutting samples

- Core Samples.

\section{Methodology}

Well logs are extensively used in petroleum exploration for identify the type of fluid and content in rocks [8]. In most subsurface studies, geophysical logs are the fundamental source of data because well logging is a very valuable method of analysing down whole formations [2], [4], [7]. In the present study, wire line logs besides the investigations of cutting samples were used to investigate the uncored facies successions, to detect changes in grain size distribution, lithology and sedimentary facies, hence to interpret depositional environment. Confirmation of the log behaviour used the cores and cutting samples. Furthermore, core to gamma-ray and spontaneous potential log correlations were set up. Petrel Software has been used in wells analysis, mapping processing and 2D geological models constructed of petroleum reservoir environment.

\section{Results and discussion}

\subsection{Lithofacies distribution of lower zeit member (cycles 3, 2 and 1)}


The south-western part of the area (Digna-1, S. Suakin-1, Bashayer-1A and Durwara wells) is dominated by terrestrial to marginal marine sediments, and partly supra tidal domain deposits where some channel feeders can support the classtic deposits distribution from south to north. The central part of the area (Suakin-1, -2, Talla-1(St). and Tokar-1(St2) wells) is dominated by shallow marginal marine to partly supra-tidal domains, where the most northern sector is dominated by the Dungunab bulge of Pre Zeit massive salt (proved by seismic interpretation)(Fig.3).

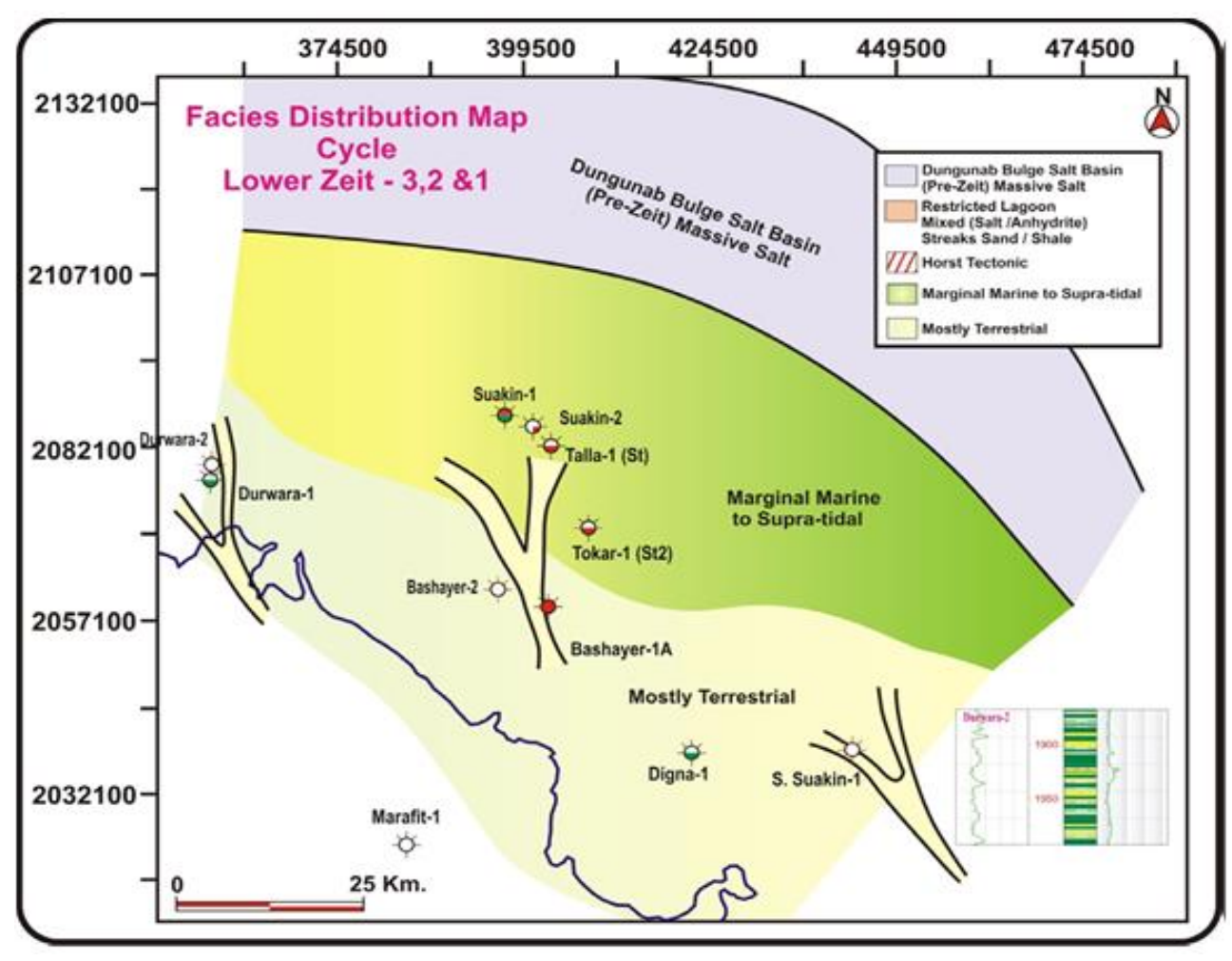

Fig. 3: Lithofacies Distribution of Lower Zeit Member (Cycles 3, 2 and1).

\subsection{Facies distribution of the lower zeit member (cycle - 4)}

During the transsigrsion of the sea level rise, the study area was covered by shallow marginal marine sediments and partially supratidal southwards. However, a fault system separates the Digna-1 well area being faulted-up where the Dungunab salt was uplifted juxtaposing the Lower Zeit (cycle 4). The central area is represented by Restricted Lagoon facies (salt-anhydrite) with sand/shale streaks. The northern Dungunab-bulge of Pre-Zeit systems still bounding such as restricted basin (Fig.4.).

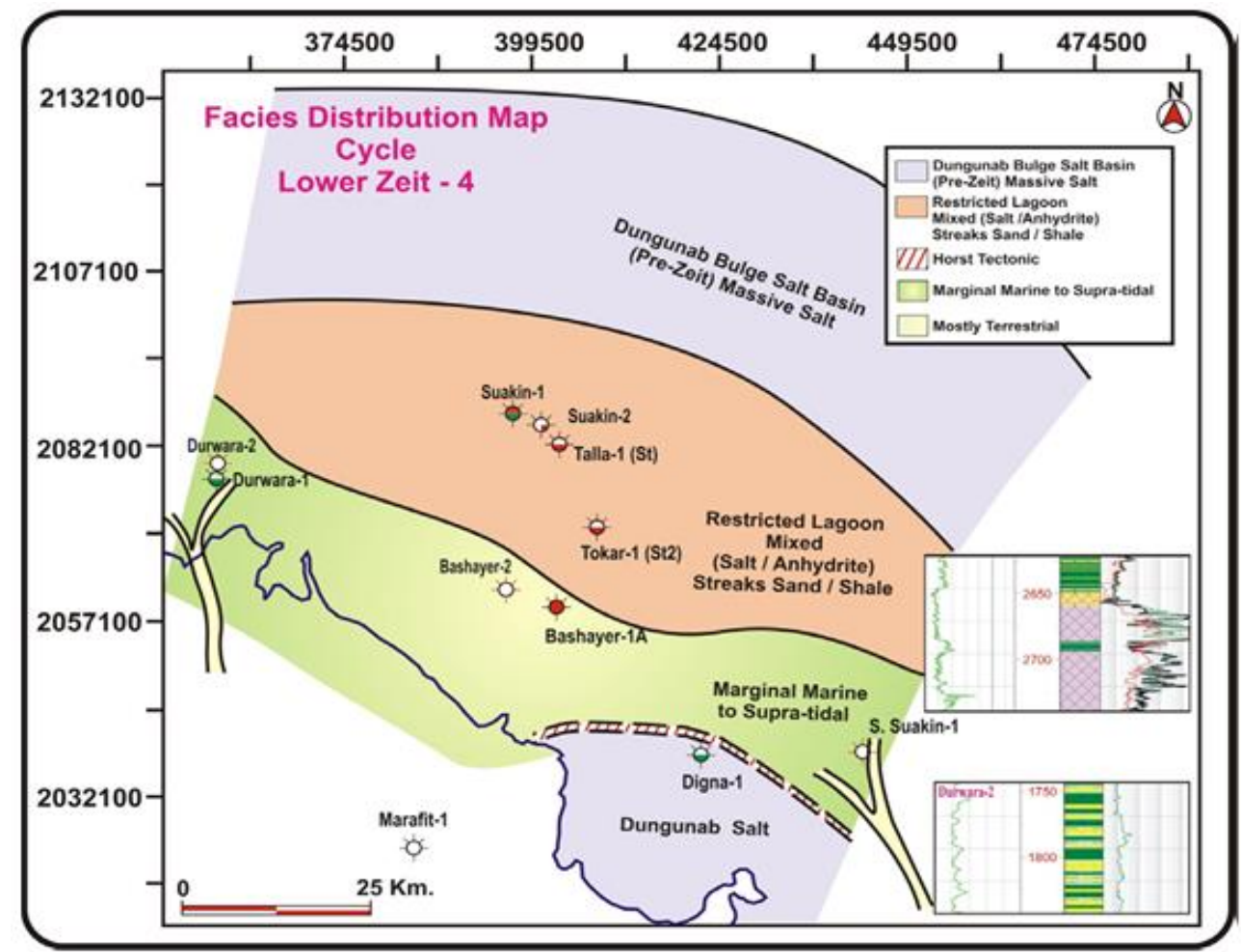

Fig. 4:Facies Distribution of the Lower Zeit Member(Cycle - 4). 


\subsection{Facies distribution of the middle zeit member (cycle -1)}

The southern sector was dominated by marginal marine to supratidal where the location of Tokar-1(St2) was included in this domain. The central area (Suakin-1, -2 andTalla-1(St) includes the restricted Lagoon facies type. In contrast, the northern Salt Bulge (Dungunab evaporite) was still high and restricting the central area. The sand distributed from south towards S. Suakin, Bashayer-1 and Durwara area (Fig.5).

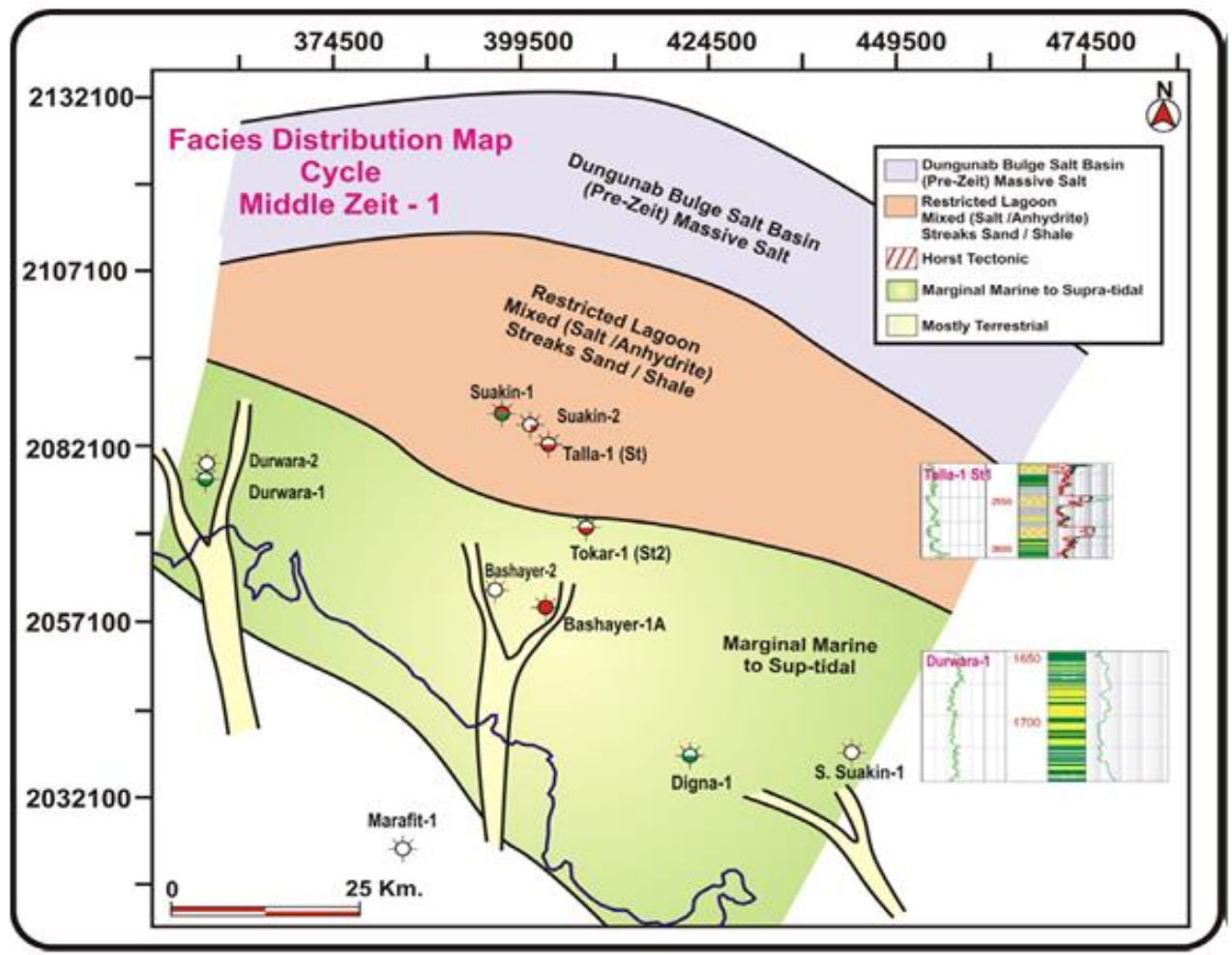

Fig. 5: Facies Distribution of the Middle Zeit Member (Cycle -1).

\subsection{Facies distribution of the middle zeit member (cycle -2)}

It is almost following the facies distribution of the underlying cycle with consideration of the sand distribution towards the Durwara area. The sandy facies is not represented in the central and south eastern sectors (Fig.6).

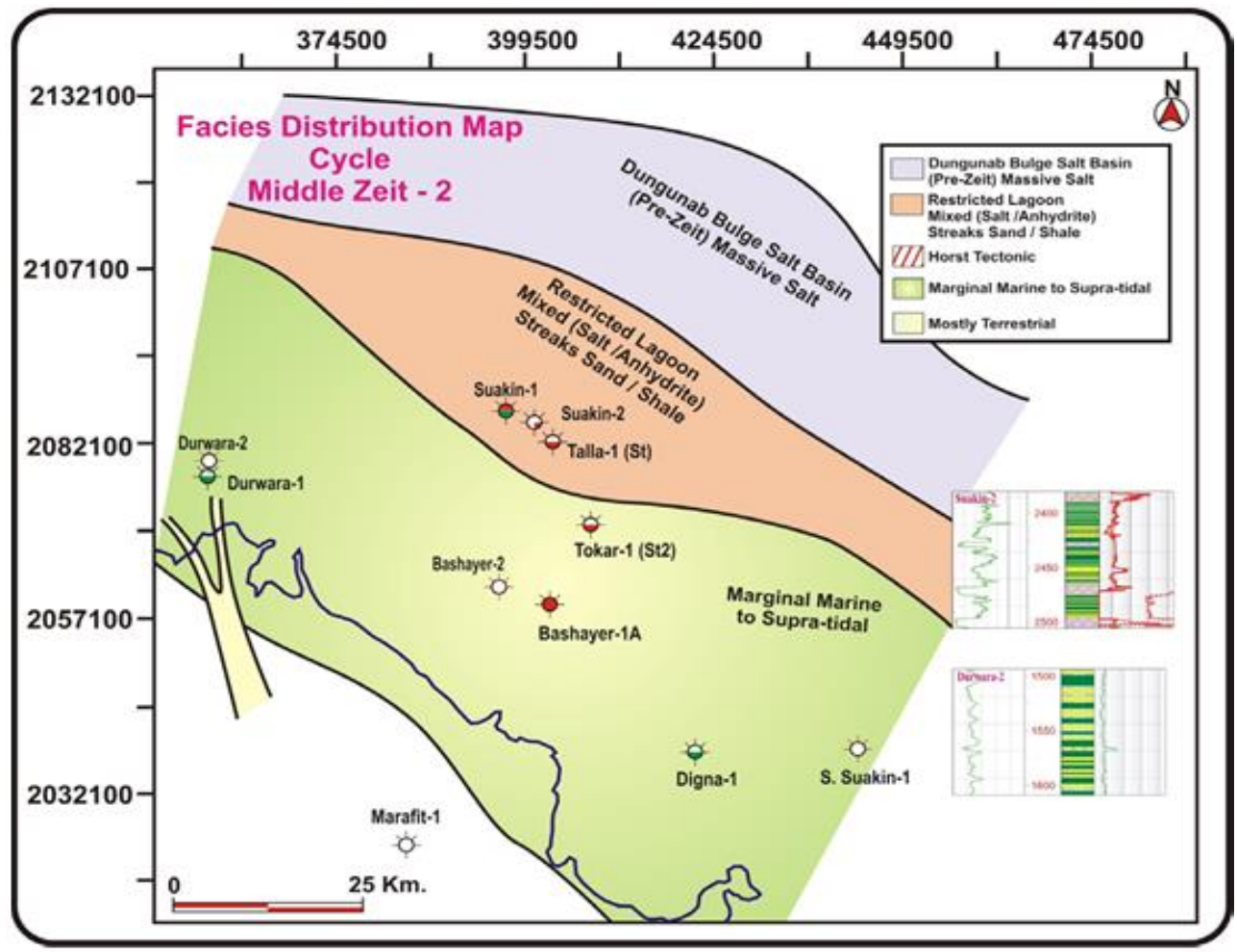

Fig. 6: Facies Distribution of the Middle Zeit Member (Cycle -2). 


\subsection{Facies distribution of the middle zeit member (cycle -3)}

In this cycle the study wells it is proved to be dominated by marginal marine facies to partially supra-tidal suites and the Northern salt bulge still restricting the central area (Fig.7).

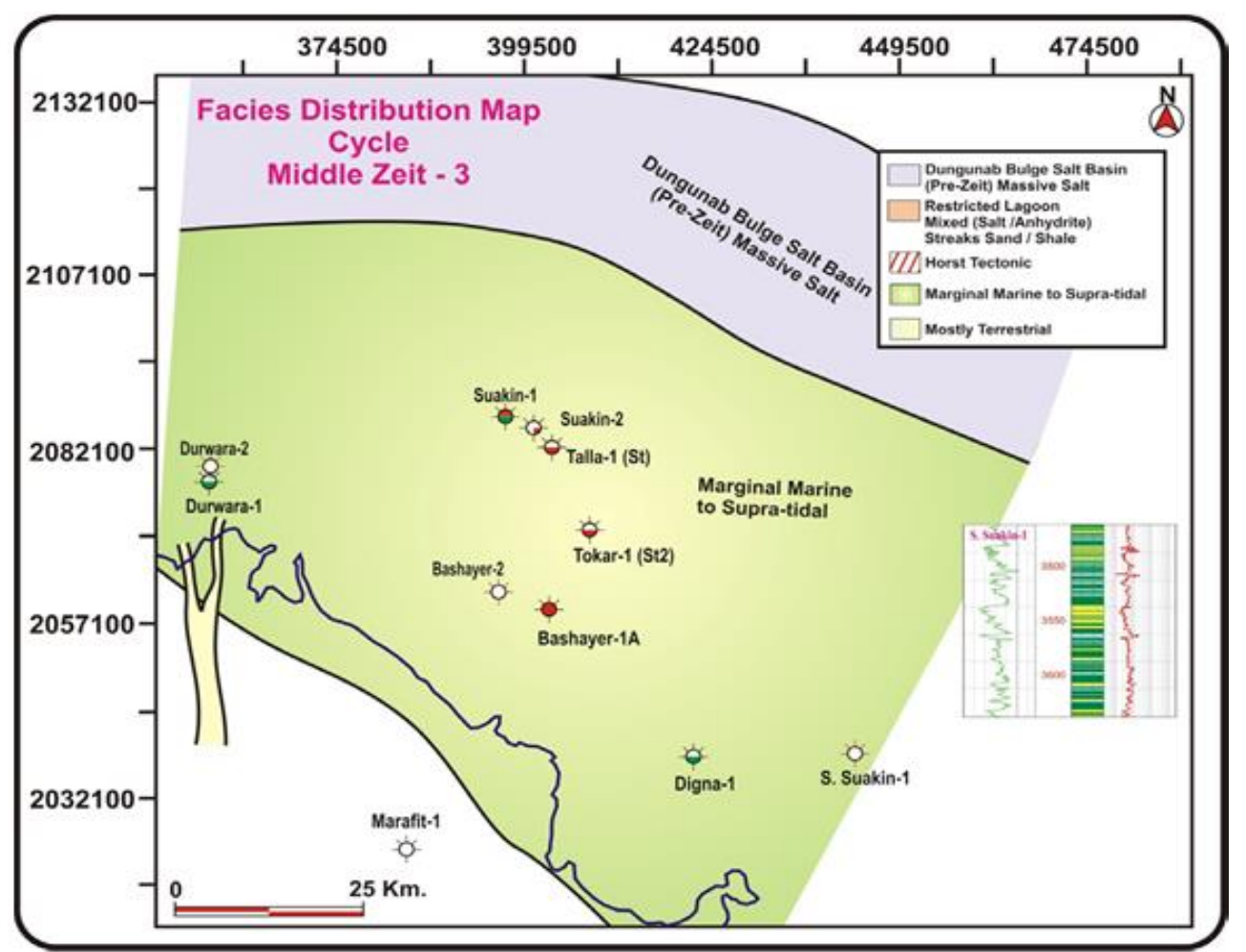

Fig. 7: Facies Distribution of the Middle Zeit Member (Cycle -3).

\subsection{Facies distribution of the upper zeit member (cycle -1)}

A preparation of facies pattern distribution being similar to that of Middle Zeit (Cycle 2), however the sandy facies influxes increased towards the S. Suakin, Digna - area, towards Bashayer area and Durwara area from south to north (Fig. 8).

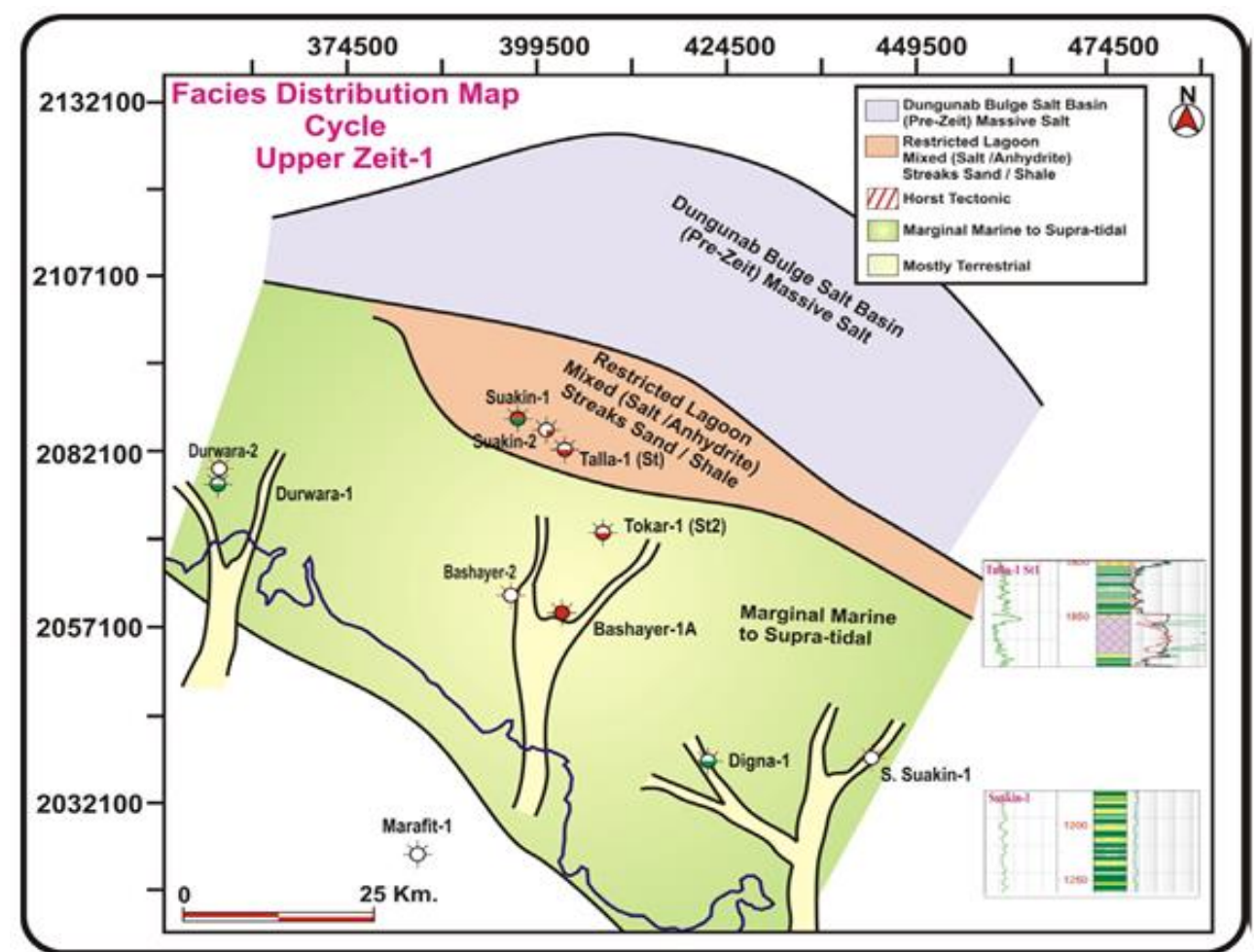

Fig. 8: Facies Distribution of the Upper Zeit Member (Cycle -1).

\subsection{Facies distribution of the upper zeit member (cycle -2)}


During this cycle, the central restricted lagoon was extended to south included Tokar-1 (St2) area. The Southern sector is dominated by marginal marine to Supra-tidal facies (Fig.9).

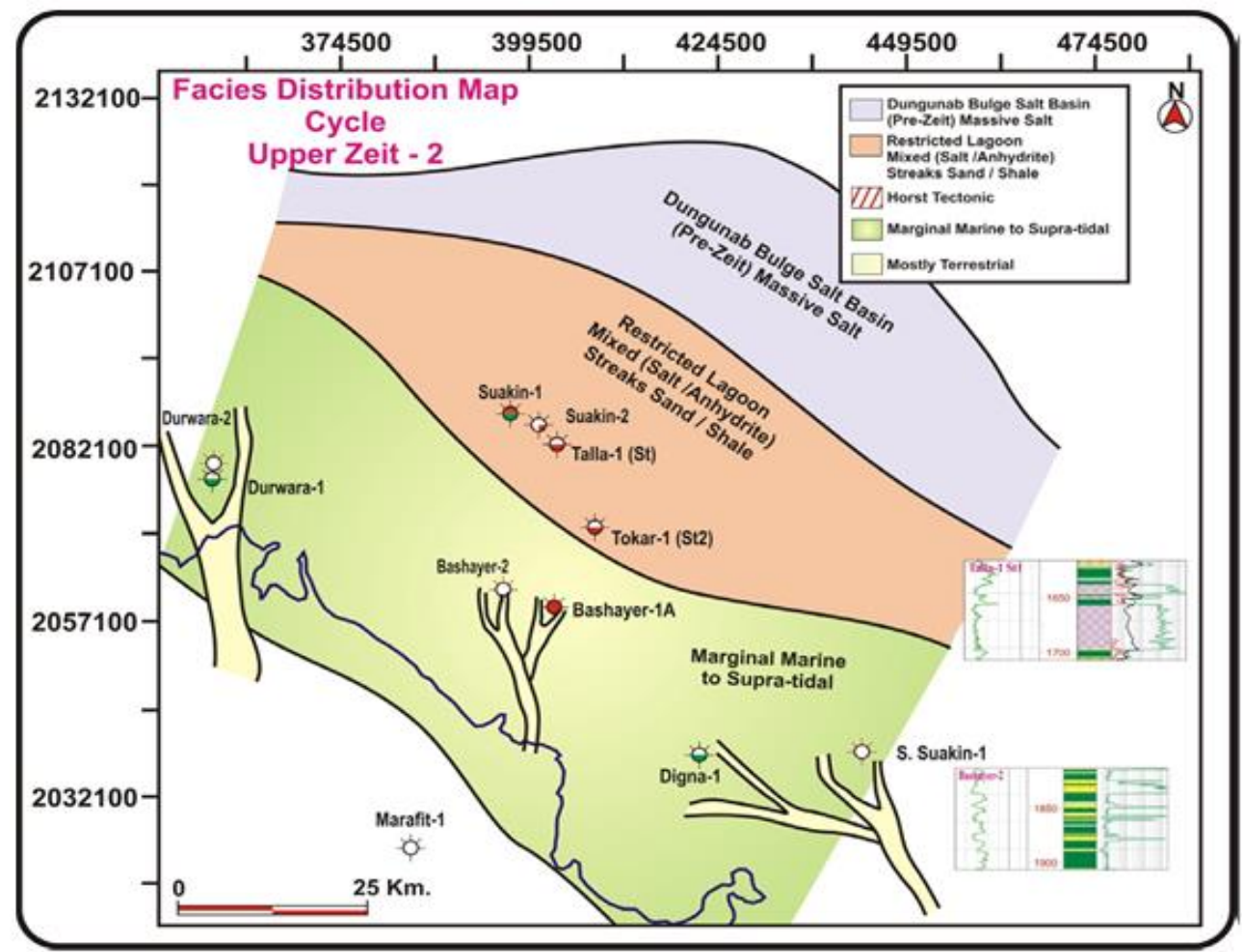

Fig. 9: Facies Distribution of the Upper Zeit Member (Cycle -2).

\subsection{Facies distribution of the upper zeit member (cycle -3)}

During the continuous restriction, the central area was expanded south to included Bashayer- area with common mixed lithotypes (salt, anhydrite, sand and shale streaks) (Fig.10).

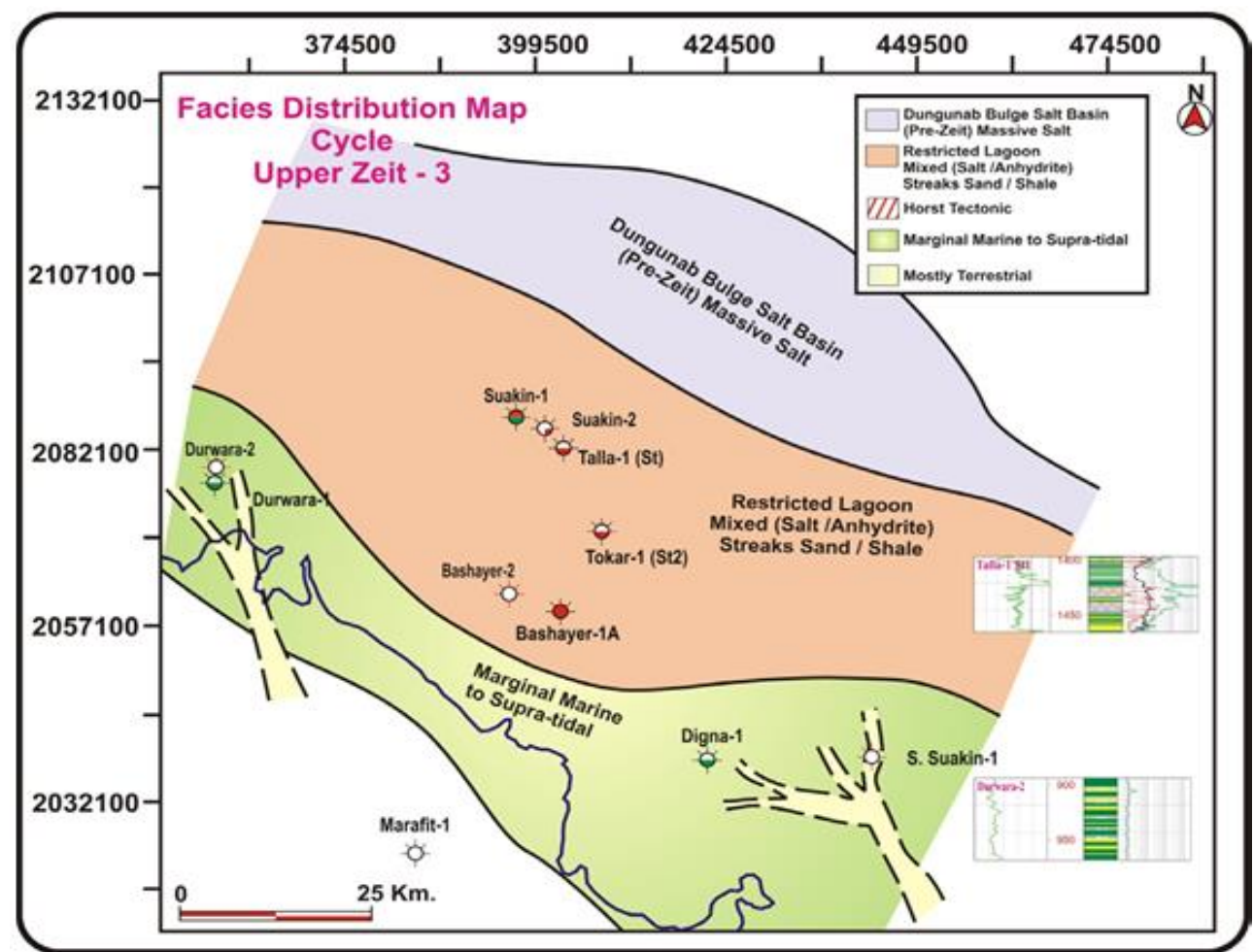

Fig. 10: Facies Distribution of the Upper Zeit Member (Cycle -3)

\section{Conclusion}

The lateral and vertical facies variations within the Zeit Formation are illustrated in cross sections and map views (Fig. 3-10). The lithofacies association and the depositional patterns of the Red Sea Basin were controlled by allocyclic and autocyclic processes. Furthermore 
these processes including tectonic, palaeoclimatic as well as depositional mechanisms. Lithofacies Distribution of the Upper Zeit Member (Cycle -A) A repeated pattern of facies distribution being similar to that of Middle Zeit (Cycle B), however the sandy facies influxes increased in thickness towards the S. Suakin, Digna- area, Bashayer area and Durwara area from south to north (Fig. 8).

During Cycle -B the central restricted lagoon was extended south to include Tokar-1 (St2) area. The Southern part is dominated by marginal marine to Supra-tidal facies (Fig.9). Cycle-C with continuous restriction, the central area was expanded south to include Bashayer 1 area with common mixed lithotypes (salt, anhydrite, sand and shale streaks) (Fig10).

The Middle Zeit Member (Cycle -A) was dominated by marginal marine to supratidal deposits where the location of Tokar-1(St2) was countered within this domain. The central area (Suakin-1, -2 andTalla-1(St) includes the restricted Lagoon facies type. In the meantime the northern Salt Bulge (Dungunab evaporite) was still high and restricting the central area. The sandy influx is from south towards S. Suakin, Bashayer-1 and Durwara area (Fig.5.). Cycle -B it is almost following the facies distribution of the underlying cycle with consideration of the sand influx towards the Durwara area, and sandy facies is not represented in the central and south eastern sectors (Fig6). Cycle -3 proved to be dominated by marginal marine facies to partially supra-tidal suites. The Northern salt bulge still restricting the central area (Fig.7).

The lower Zeit Member (Cycles C, B and A) shows the southwestern part of the area (Digna-1, S. Suakin-1, Bashayer-1A and Durwarawells) is dominated by terrestrial to marginal marine and partially supra tidal domain where some channel feeders acting as indicators of sand distribution from south to north. The central part of the area (Suakin-1, -2, Talla-1(St) and Tokar-1(St2) wells) is dominated by shallow marginal marine to partially supra-tidal domains, where the most northern part is dominated by the Dungunab bulge of Pre Zeit massive salt (Fig.3.). During the relative gradual sea level transsigrission the Lower Zeit Member (Cycle -D) was covered by shallow marginal marine sediments and partially supratidal deposits to southwards. However, a normal fault system separates the Digna-1 well area being on horst where the Dungunab salt was uplifted juxtaposing the Lower Zeit (cycle D). The central area is represented by restricted Lagoon facies (salt-anhydrite) with sand/shale streaks. The northern Dungunab-bulge of Pre-Zeit systems still bounding such restricted basin (Fig.4)

\section{Acknowledgement}

Authors were indebted to Ministry of Petroleum, Petroleum Labs\& Researches and Studies most of data and direct support during field work in the study area; and also thanks to International University of Africa, Faculty of Minerals and Petroleum for generous support which helped to improve the manuscript.

\section{References}

[1] Ali, A.S., and Mohammed, B. F., (1991): The ecology of the Red Sea Coast of the Sudan: Environment and vegetation .RESAP Technical Papers. NO.4. Univ. of Khartoum, Sudan.

[2] Allen, P. A. and Allen, J. R. (1990): Basin Analysis: Principles and Applications, 451 p., Blackwell Scientific Publications, Oxford.

[3] Babikir, I.A.A. (1994): Investigation on the Recent Sedimentology of Khor Eit, Red Sea Coast, Sudan. M.Sc. Thesis. Geol. Dept. Khartoum University, Sudan.

[4] Cant, D. J. (1984): Subsurface facies analysis. In Facies Models (Ed. by R. G. Walker). Geosciences, pp. 299-308, Canada.

[5] Eltayib, S.H.M.A. (2016): "Tectono-Sedimentlogical and Stratigraphic Development of the Sudanese Red Sea Coast (Block-15) PhD Thesis Omdurman Islamic University", unpublished.

[6] Eltayib, S.H.M.A. (2018): Sedimentary Petro graphic Characteristics of Zeit Formation (Suakin -1 Well) in Sudanese Red Sea Basin. International Journal of Innovation in Science and Mathematics (IJISM) Vol.6, Issue3, 2347-9051.

[7] Miall, A. D. (1984): Principles of sedimentary basin Analyses, 490 p., Springer-Verlag, New York.https://doi.org/10.1007/978-1-4757-4232-9.

[8] Tucker, M. E. (1991): Sedimentary petrology: An introduction to the origin of sedimentary rocks (second edition). Blackwell Scientific Publications, 260 p., Oxford. 